\title{
CHANGES IN MANAGEMENT TO ACHIEVE HIGHER MILKFAT PRODUCTION ON THE WEST COAST
}

\author{
M. C. WHEADON
}

N.Z. Dairy Board Consulting Officer, Nelson

\section{Abstract}

Based on research findings and observation, a dairy farm pasture management system is presented that could result in an increased per hectare milkfat production and profitability.

In autumn there should be a change away from milk production towards pasture management and cow condition by using strategic drying off of cows relevant to the individual farm situation. This is probably the most important decision made each year.

As winter pasture production is inadequate to meet cow maintenance and pregnancy requirements, cow condition should be at the level required for calving by the start of winter. The use of supplements conserved from summer' surpluses to specifically 'in-" crease cow condition in winter is of marginal economic value. They should be used primarily in autumn to produce extra pasture to be available for later use in winter.

The matching of correct drying-off date, calving date and stocking rate to the pasture growth curve for the region, and an appreciation of correct feeding levels at the different stages of lactation are important.

\section{INTRODUCTION}

The West Coast has 288 dairy farms. They extend from Karamea in the north to Whataroa in the south, a distance of $320 \mathrm{~km}$ by road.

Based on data from the 'Karamea and Westland Co-operative Dairy Companies for the 1978-9 and 1979-80 seasons the average West Coast dairy farm has 114 cows, and produces $15700 \mathrm{~kg}$ milkfat - that is, $138 \mathrm{~kg} / \mathrm{cow}$, or $190 \mathrm{~kg} / \mathrm{ha}$ with replacements grazed off (estimated) .

Accepting that higher milkfat prodution could be achieved by improving the genetic merit of herds, this paper will examine an alternative strategy for increasing production - - that is, the better utilization of the plant dry matter growing at different seasons by the stock of existing genetic merit.

The necessary changes in management will be discussed in the context of the seasonal pattern of growth of what is considered an 
average pasture at a stocking rate of 2 cows/ha. The district's present stocking rate would approximate 1.4 cows/ha. If replacements were carried, this would mean a $15 \%$ reduction in the number of cows milked.

The farming year will be considered as the four seasons in the following order, March to May (autumn)) June to August (winter), September to November (spring) and December to February (summer). The seasonal distribution of milkfat production (1974-5 to $1979-80$ inclusive), is autumn $26 \%$, winter 0, spring $34 \%$ and summer $40 \%$.

The typical seasonal distribution of pasture yield is shown in Fig. 1.

\section{AUTUMN}

Autumn was used as a starting point because it was considered decisions made here have considerable influence over the following season's production.

Continuing to milk the whole herd on from 1st March is only economic when:

- a system of grazing can be adopted that will create an adequate build up of pasture for use in the winter and the spring. - each herd member is at a condition score (C.S.) of $4 \frac{1}{2}$ or better.

An appropriate grazing system for the autumn is one where the area grazed daily is reduced from one-thirtieth of the farm's pasture in early March to one-ninetieth of the farm's pasture by the end of May. If this is not possible without restriction of the herd's level of intake, their diet could be supplemented with hay or silage.

A grazing system that builds up pasture also builds up root reserves. These improve pasture recovery following grazing (Smetham, 1972).

One hard grazing in early autumn followed by a lax grazing has been shown to give recently formed tillers a suitable environment for establishment (Tainton, 1974). These tillers are the basic units for the coming winter and spring pasture sward. This hard grazing should also result in a sward containing fewer clumps. At the approach of winter when pasture is a a premium, it is important to have all of the farm growing grass, remembering it all receives lime and fertilizer.

Cow condition should be monitored continually over this autumn period. The following programme is recommended where the condition of individual herd members is less than a C.S. of 


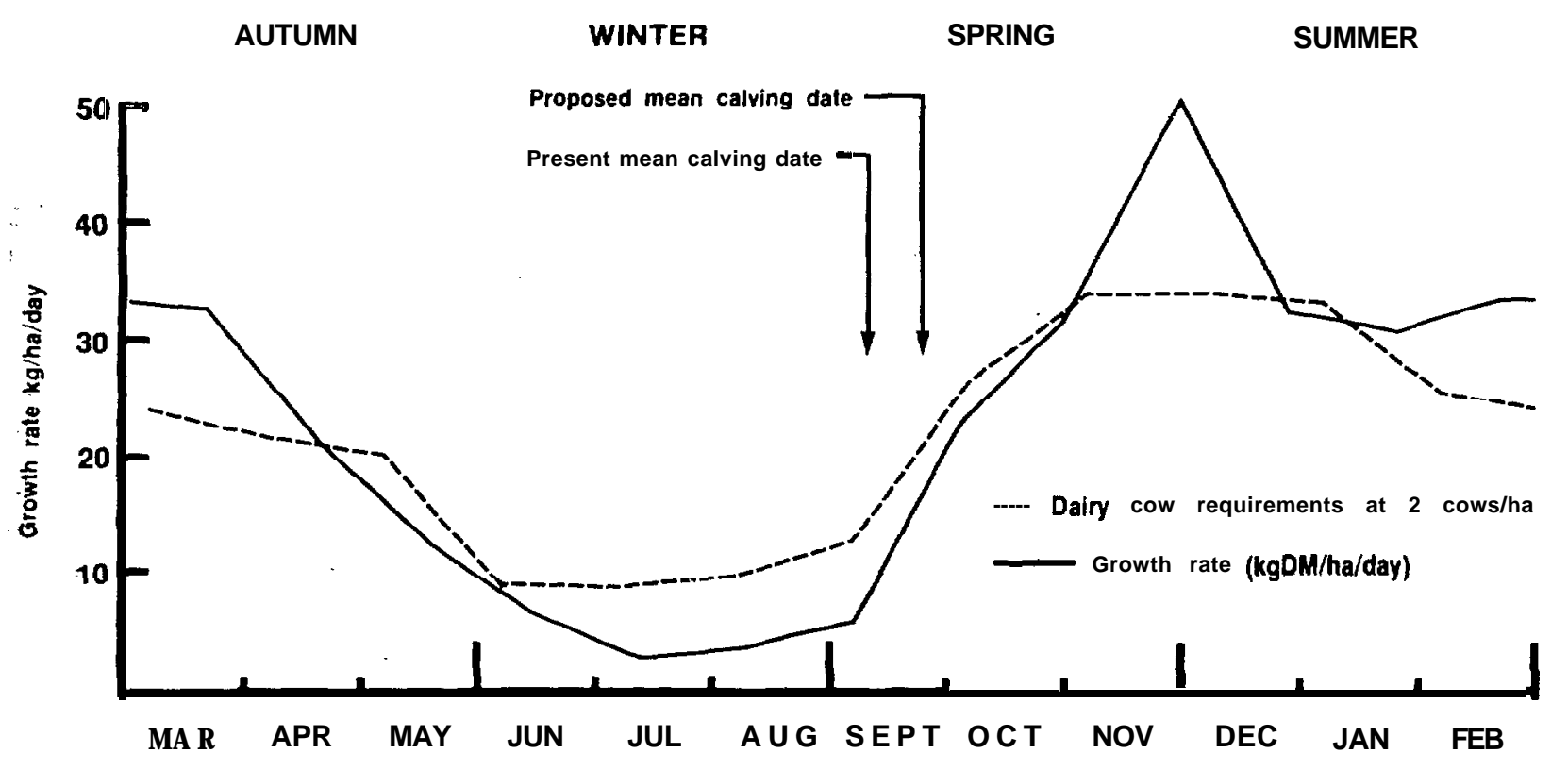

Fig. 1: Typical seasonal distribution of pasture yield. 
$4 \frac{1}{2}$ : Sell culls, dry off any cows below C.S. $4 \frac{1}{2}$, dry off all remaining first-calvers, dry off remainder of herd early as necessary.

The early sale of cull cows reduces the competition for the available pasture amongst the remaining herd members. This does not necessarily result in reduced daily milkfat production. It could even increase if the available feed is eaten by the more efficient cows that remain. Drying off cows that are to remain on the property reduces their requirements below that of a lactating cow at this stage of the season.

The daily level of milk production at this stage of the season should not influence the above programme.

The management of dry cows that are not culled is important. For them to gain in condition they will need to be on an "above maintenance" level of feeding. Their retention in the milking herd is normally one way this can be achieved.

\section{WINTER}

The use of the autumn grazing system described should result in a bank of pasture to take into the winter.

Ruakura work on winter rotation lengths over the past two years (A. M. Bryant, unpub.) has shown that one complete rotation from drying off to calving is better than shorter rotations, as it provided a better level of feeding in late pregnancy and ample feed in the post-calving period.

For an 80 ha farm carrying 160 cows, a 100-day rotation will result in 0.80 ha being grazed per day, or a stocking rate of 200 cows/ha.

The requirements of the herd over the winter are increased if maintenance plus liveweight gain is required. A cow at a C. S. 4 requires an extra $210 \mathrm{~kg}$ DM (Grainger, 1980) over and above her maintenance requirements to reach a C.S. 5. The time required to increase liveweight by 1 C.S. is dependent on type and daily amount of feed eaten (Table 1).

To achieve the maximum intake of $14 \mathrm{~kg}$ DM/cow with pasture, it would require cows to be grazed ad lib., and with a minimum of $1200 \mathrm{~kg} \mathrm{DM} /$ ha remaining after grazing. If a herd at C.S. 4 on 1 June was to reach C.S. 5 at calving on 1 September, approximately one-third more DM is required over the dry period than one already at C.S. 5.

With emphasis on cow condition in the autumn, coupled with the lengthening of the grazing rotation, a wintering programme 
TABLE 1: MAXIMUM VALUES FOR APPETITE AND RATE OF GAIN IN CONDITION SCORE (C.S.) BY DRY COWS FED ON PASTURE OR HAY

(Holmes \& McLenaghan, unpub.)

\begin{tabular}{lccc}
\hline Feed & $\begin{array}{c}\text { Digestibility } \\
(\%)\end{array}$ & $\begin{array}{c}\text { Maximuna intake } \\
(\mathrm{kg} D M / \text { cow } / \text { day })\end{array}$ & Rate of change in C.S. \\
\hline Pasture & $\mathbf{7 5}$ & 14 & +1 in 33 days \\
Medium hay & $\mathbf{5 0}$ & 9 & No change \\
Good hay & 50 & 10 & +1 in 210 days \\
\hline
\end{tabular}

using up to a $75 \%$ grass diet should be possible, making the following assumptions.

A pasture with $1200 \mathrm{~kg}$ DM base cover at 1 June, and an average winter growth rate of $4 \mathrm{~kg} \mathrm{DM} /$ ha/day (Fig. 1), will have a total winter growth (June-August inclusive) of $360 \mathrm{~kg}$ $\mathrm{DM} / \mathrm{ha}$, resulting in a total standing yield of $1560 \mathrm{~kg} \mathrm{DM} / \mathrm{ha}$. An average winter grazing consumes $860 \mathrm{~kg} \mathrm{DM} / \mathrm{ha}-i . e$., there is a residual of $700 \mathrm{~kg} \mathrm{DM} / \mathrm{ha}$. One $400 \mathrm{~kg}$ liveweight cow at C.S. 5 requires $600 \mathrm{~kg}$ DM over winter to calving. With a stocking rate of 2 cows/ha, $1200 \mathrm{~kg}$ of $\mathrm{DM} /$ ha will be required for wintering purposes.

The resultant deficit is $340 \mathrm{~kg} \mathrm{DM} /$ ha, representing 21 bales of hay, or 11 bales/cow. The pasture eaten represents $75 \%$ of the cow's total winter requirements.

A herd at C.S. 4 at June, if it is to reach C.S. 5 at calving, would require an extra $210 \mathrm{~kg}$ DM over the winter period. This represents an extra 13 bales/cow requirement. Even with this she may not necessarily reach C.S. 5 (Table 1).

A level of grass feeding at approximately $75 \%$ of their diet would not necessitate water being available on a regular basis. Back fencing at all times to encourage pasture recovery is recommended.

\section{SPRING}

From calving, the requirements of cows, irrespective of the level of feeding, cannot be met (Wallace, 1955). Cow condition will be lost in favour of milk production (Wallace, 1955). This can be minimized where feeding is unrestricted on a grass diet.

To achieve this, grazing a leafy pasture carrying 2000 to 2500 $\mathrm{kg} \mathrm{DM} / \mathrm{ha}$ is recommended. If a minimum of $1200 \mathrm{~kg} \mathrm{DM} / \mathrm{ha}$ (Bryant, 1980) remains after grazing, full feeding and hence optimum feed intake and high production should result.

The importance of maintaining a rotation length at this period to maximize pasture yield can be illustrated by the results from 
a frequency cutting trial carried out on the West Coast for three years. Over the spring period, cutting at 2-and 4-weekly intervals gave growth rates of 32 and $47 \mathrm{~kg} \mathrm{DM} / \mathrm{ha} /$ day, respectively, a $50 \%$ increase in pasture yield with the longer interval (J. D. Morton, unpub.) . However, the growth rate will also depend on residual pasture remaining after grazing.

A herd calving at C.S. 5 or better, and being fully fed after calving, should peak on a per cow basis at $0.9 \mathrm{~kg}$ milkfat/day plus, 6 weeks from the herd's mean calving date - i.e., midNovember. Some farmers on the West Coast, who have been able to meet the above criteria, are achieving this peak level of production.

The contribution made by cow condition to. the new season's milkfat production is shown in the first 140 days of lactation, as being $0.06 \mathrm{~kg}$ milkfat/cow/day on average for each condition score increase (Grainger, 1980) above score 4.

If, despite the autumn/winter management outlined, farmers find the cows low in condition and their feed intake restricted following calving, then a review of either calving date or stocking rate is necessary. The present mean calving date of 10 September results in a period following calving when underfeeding results (Fig. 1). A mean calving date from 20 September (i.e.,, start calving from 4 September) would suit most farms at a stocking rate of 2 cows/ha.

Peak per cow production is normally reached about midNovember. It is at this stage that seed-head emergence is becoming evident, which results in a deterioration in pasture quality. A change in emphasis from the cow's needs towards pasture control is recommended at this time.

\section{SUMMER}

Pasture production more than meets the requirements of the milking herd over the summer period (Fig. 1). The intensity of grazing should be such as to result in a quality pasture being available at subsequent grazings, quantity of feed on offer being rarely of concern. A herd that has reached its peak level of production should hold its production at or near that level on this type of sward.

Mating has generally commenced from late November. By maintaining a high level of pasture intake, body-weight' losses which have been taking place since calving should be minimized, and thus help increase both submission rates and conception rates, particularly so in the case of the 2-year-olds (McClure, 1958). 
Feed, surplus to the requirements of the herd, when identified, should be set aside for conservation. Emphasis should be placed on the word "surplus." If there is no surplus, no supplements should be made. Underfeeding at this stage ( 3 to 5 months from calving) in the lactation can. only result in a drop in daily milkfat production. The primary purpose of conservation is in the maintenance of a quality pasture, not in the accumulation of supplements for use in the following winter.

The summer pasture surplus (Fig. 1) is sufficient to meet the winter feed deficit under the 2 cow/ha example provided cow condition and pasture accumulation are adequate at the onset of winter.

In conclusion, this paper has discussed changes to management currently being practised on West Coast dairy farms. Priority decisions at each season have been highlighted, with particular attention being paid to matching animal requirements with the pasture growth pattern, and the "shifting" of feed for winter use as both autumn-saved pasture and summer conservation. Overall, if more emphasis was placed on increasing the spring and summer milkfat production (75\% of the total) and less on the amount of milkfat produced in the autumn, a greater total for the season should' result.

A stocking rate of 2 cows $/$ ha and $300 \mathrm{~kg}$ fat $/ \mathrm{ha}$ is possible on most West Coast farms. In the more favoured areas, production levels approaching $400 \mathrm{~kg}$ fat/ha could be achieved. If these farms were self-contained, the per hectare production could be expected to be reduced by approximately $15 \%$. It is very much a case of making better use of the pasture that is currently being grown.

\section{ACKNOWLEDGEMENTS}

Appreciation is expressed to J. D. Morton, Scientist, MAF, Greymouth, for his assistance in writing the paper and to the executive staff of the Karamea and Westland dairy companies for providing milkfat production information.

\section{REFERENCES}

Bryant, A. M., 1980. Proc. N.Z. Soc. Anim. Prod., 40: 50-8.

Grainger, C., 1980. Dairyfmg. A.: 65.

McClure, T. J., 1958. Proc. Ruakura Fmrs' Conf.: 260.

Smetham, M. L., 1972. Pastures and Pasture Plants (Ed. R. H. M. Langer).

Tainton, N. M., 1974. J. Br. Grassld Soc., 29: 191.

Wallace, L. R., 1955. Proc. R uakura Fmrs' Conf.: 210. 